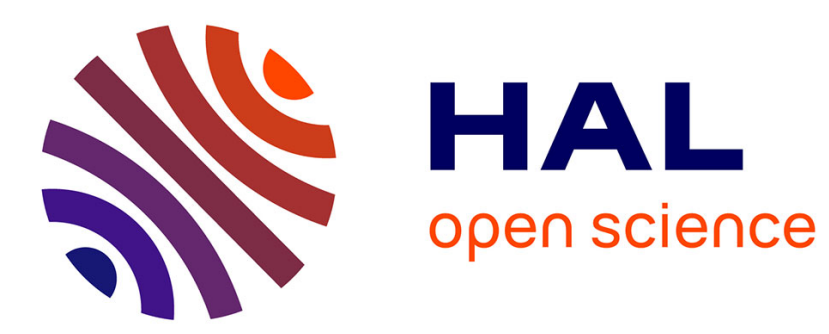

\title{
Spatial aggregation of phoretic mites on Bombus atratus and Bombus opifex (Hymenoptera: Apidae) in Argentina
}

Pablo Revainera, Mariano Lucia, Alberto Abrahamovich, Matias Maggi

\section{To cite this version:}

Pablo Revainera, Mariano Lucia, Alberto Abrahamovich, Matias Maggi. Spatial aggregation of phoretic mites on Bombus atratus and Bombus opifex (Hymenoptera: Apidae) in Argentina. Apidologie, 2014, 45 (5), pp.579-589. 10.1007/s13592-014-0275-4 . hal-01234756

\author{
HAL Id: hal-01234756 \\ https://hal.science/hal-01234756
}

Submitted on 27 Nov 2015

HAL is a multi-disciplinary open access archive for the deposit and dissemination of scientific research documents, whether they are published or not. The documents may come from teaching and research institutions in France or abroad, or from public or private research centers.
L'archive ouverte pluridisciplinaire HAL, est destinée au dépôt et à la diffusion de documents scientifiques de niveau recherche, publiés ou non, émanant des établissements d'enseignement et de recherche français ou étrangers, des laboratoires publics ou privés. 


\title{
Spatial aggregation of phoretic mites on Bombus atratus and Bombus opifex (Hymenoptera: Apidae) in Argentina
}

\author{
Pablo Revainera ${ }^{1}$, Mariano Lucia ${ }^{2,3}$, Alberto Horacio Abrahamovich ${ }^{2,3}$, \\ Matias MAGGI ${ }^{1,3}$ \\ ${ }^{1}$ Laboratorio de Artrópodos, Facultad de Ciencias Exactas y Naturales, Universidad Nacional de Mar del Plata, \\ Funes 3350, 7600, Mar del Plata, Argentina \\ ${ }^{2}$ División Entomología, Museo de La Plata, Universidad Nacional de La Plata, Paseo del Bosque s/n, 1900FWA, \\ La Plata, Argentina \\ ${ }^{3}$ CONICET, Consejo Nacional de Investigaciones Científicas y Técnicas, Rivadavia 1917, C1033AJ, Buenos Aires, \\ Argentina
}

Received 1 June 2013 - Revised 9 January 2014 - Accepted 5 February 2014

\begin{abstract}
Mites have been observed on the bumblebee's body and inside their nest for over 150 years, and parasitic relationships between them have occasionally been reported. One of the most interesting animal associations between mites and bees is phoresy. At present, no study has evaluated the distribution patterns of phoretic mites on bumblebees nor the factors that might be influencing such association. The main goal of this research was to determine whether an aggregation of external mites on bumblebees is influenced by (a) the phoretic mite load per bee, (b) the host species, (c) the caste of bumblebee, (d) the interaction between mite load and bee species, and (e) the presence of a suitable physical place for the mites to accommodate on the bee body. The following mite species were recorded on Bombus atratus and Bombus opifex: Kuzinia laevis, Kuzinia americana, Kuzinia affinis, Kuzinia sp., Pneumolaelaps longanalis, Pneumolaelaps longipilus, Scutacarus acarorum, and Tyrophagus putrescentiae. Our results indicate that Kuzinia mites have a strong preference for a particular region on the propodeum, which has shorter hairs than on most areas of the body. In addition, generalized linear model analysis demonstrated that mite aggregation was influenced by the caste and host species.
\end{abstract}

bumblebees / phoretic mites / aggregation

\section{INTRODUCTION}

Mites have long been associated with bees, often showing a close relationship among particular taxa, probably as a result of a coevolutionary process (Klimov et al. 2007). Records of these relationships are widely available, but the biological understanding of such relationships is still limited. A mite-bee

Corresponding author: P. Revainera, pablo_re04@hotmail.com Manuscript editor: James Nieh association could lead to different interactions, ranging from negative impacts on the bees to the potential benefits to them (Chmielewski 1971). The best-known negative association between mites and bees is that between Varroa mites and honeybees. These ectoparasitic mites feed on the bee's hemolymph, weakening the bee and often leading to the death of the colony (Sammataro et al. 2000). The genetic structure of the Varroa populations, its reproduction, and its negative impacts on the bee colonies have been widely reported (Maggi et al. 2009, 2010, 2011b, 2012; Rosenkranz et al. 2010). However, the associations of mites on other 
bees are poorly understood (e.g., Fain et al. 1999; Fain and Pauly 2001; Waiter et al. 2002).

One of the most interesting animal associations is phoresy. Farish and Axtell (1971) proposed that phoresy is a phenomenon in which one animal actively seeks out and attaches to the outer surface of another animal for a limited time during which the attached animal (termed the phoretic) ceases both feeding and ontogenesis. Such attachment presumably results in dispersal from unsuited to suited areas for further development, either of the individual or its progeny. Phoresy occurs, for example, in some species of bees that can carry one or several mite species, usually the heteromorphic deutonymphs (non-feeding instars), which complete their life cycles inside the bee nest. Both bees and mites might benefit from this association. Mites reach a safe place for reproduction (besides ensuring food resources and protection against potential predators), and bees become favored by the mites, which feed on potentially harmful microorganisms from the surface of the pollen-nectar sources (Schwarz and Huck 1997). The presence of special areas or "acarinaria" on the bee body in which mites are transported provides a secure place for them. In many species of solitary bees (genera Ctenocolletes of the family Stenotritidae; Thectochlora and Lasioglossum of Halictidae; and Xylocopa, Ceratina, and Tetrapedia of Apidae), this acarinarium is the result of modified external morphological structures (McGinley 1986; O'Connor and Klompen 1999; Engel 2000; Klompen et al. 2007). No information concerning the acarinaria on bumblebees has yet been reported. As suggested by Klimov et al. (2007), true acarinaria are not simply induced by the mites' presence, but from changes in the host's body over evolutionary time to accommodate the mites. Nevertheless, Abrahamovich and Alzuet (1989) defined another type of acarinarium: a functional one, where mites are safely transported even when no drastic morphological changes are observed on bees. Whatever the location of an acarinarium in the bee or its morphological complexity, a consequence of this structure is the grouping of mites.

Bumblebees (genus Bombus Latreille) are among the most efficient insect pollinators in natural and agricultural ecosystems (Abrahamovich et al. 2001; Goulson 2003). Mites have been observed on bumblebees and in their nests for over 150 years (Husband 1968). These associations have been studied by several authors including Chmielewski (1971, 1977, 1998), O'Connor (1988), Houck and O'Connor (1991), Schwarz et al. (1996), Huck et al. (1998), Chmielewski and Baker (2008), and Maggi et al. (2011a). These ecological interactions among mites and bees vary in form and complexity, ranging from strictly phoresy to parasitism (O’Connor 1988), but no studies have evaluated the distribution patterns of phoretic mites on bumblebees and the factors that influence them. Reports of mites other than Varroa infesting honeybees suggest that mite distribution on the bee body is aggregated and significantly differs from a Poisson distribution (Le Conte et al. 1990; Floris 1991; Donzé et al. 1996). The authors of these studies indicated that mite aggregation suggests differences in the chemostimuli triggering infestation, such as higher production of kairomones from the bee host, deposition of chemical trails, or emission of an aggregation pheromone by the infesting mites.

Here, we studied external mites on bumblebees to determine whether aggregations are influenced by (a) the phoretic mite load per bee, (b) the host species, (c) the bumblebee caste, (d) the interaction between mite load and bumblebee species, and (e) the presence of a suitable physical place for mite accommodation on the bumblebee body. We hypothesized that mites modify the density of their aggregation on the host bee accordingly to (a) density-dependent phenomena, (b) the caste of the bumblebee species that they are infesting, and (c) the area of the bee body on which they aggregate. In addition, we provide information on the ecological relationships of mites infesting Bombus in the neotropical region.

\section{MATERIALS AND METHODS}

\subsection{Bombus survey}

We surveyed mites on a total of 668 bumblebee specimens of Bombus atratus and Bombus opifex 
from three entomological collections in Argentina: IFML (Fundación e Instituto Miguel Lillo, Tucumán), IADIZA (Instituto Argentino de Investigaciones de las Zonas Aridas, Mendoza), and MLP (Museo de La Plata, La Plata). These bumblebee specimens are drymounted (pinned) and were collected between 1945 and 1986 from ten provinces in Argentina: Buenos Aires, Catamarca, Córdoba, Entre Ríos, Formosa, Jujuy, La Rioja, Mendoza, Salta, and Tucumán. Photographs of Bombus were taken with a Canon Power Shot ${ }^{\circledR}$ A520 digital camera attached to a Nikon SMZ 745T stereomicroscope. Digital images were edited using the Combine $\mathrm{ZM}$ open source software (Hadley 2011).

\subsection{Mite extraction and identification}

We recorded the number of mites and the location on the bee body where they were found (e.g., groove between pronotum and scutum, under the tegula, propodeum and sterna, etc.). Mites were fixed in $70 \%$ alcohol prior to examination. Lactic acid (50\%) was used to clear mites for routine examination and sorting. For identification of mites, specimens were mounted in Oudemans' fluid (as recommended by Hughes 1976) on microscope slides. Mite identification was conducted using acarological literature (Zachvatkin 1941; Hunter 1966; Hunter and Husband 1973; Putatunda et al. 1983; Krantz and Walter 2009). For each bee inspected, we recorded the mean abundance, mean intensity, and prevalence, as indicated by Bush et al. (1997) and Rózsa et al. (2000). Mean abundance was calculated as the arithmetic mean of the number of individuals of a particular mite species per host examined. Mean intensity was calculated as the arithmetic mean of the number of individuals of a particular mite species per infested host in a sample. Mite prevalence was calculated as the percentage of individuals of a particular host species (B. atratus or B. opifex) harboring a particular mite species. The same parameters were also recorded for queens, males, and workers of each Bombus species.

\subsection{Kuzinia aggregation, data modeling, and statistical analysis}

Taking into account that preserved bees from entomological collections were used to indentify patterns of mite aggregation, only Kuzinia mites were used to establish the presence/absence of a visibly recognizable cluster of mites. We chose these mites because they present heteromorphic deutonymphs, which stay attached to their host even after they die. The presence of mite aggregation was only recorded when more than two mites were found attached in the same place and were in close contact with each other. Mites scattered on the bee body were not considered as an evidence of a mite aggregation and were excluded from the counts. More than one mite aggregation could be present in a single bee.

Prior to data modeling, exploratory analyses of the data were carried out to identify (a) outliers, (b) collinearity among the explanatory variables, and (c) interaction among the explanatory variables. This analysis was intended to avoid violations of the underlying assumptions of the statistical techniques employed in this study (type I or type II errors, outliers, heterogeneity of variance, collinearity, dependence of observations, problems with interactions, double zeros in multivariate analysis, zero inflation in generalized linear modeling, and the correct type of relationships between dependent and independent variables). High collinearity between variables results in great variances for the regression coefficients (Montgomery and Peck 1992). Thus, in the presence of collinearity between variables, it was necessary to choose only one of them to be included in the final model. A more detailed explanation of exploratory analyses can be found in Zuur et al. (2010), who suggest that researchers must conduct a preliminary descriptive analysis to infer the variables that should be included in the final model.

After the initial exploration, data on the presence of Kuzinia mite aggregations $\left(\mathrm{KAc}_{\mathrm{ij}}\right)$ per bumblebee were analyzed using the generalized linear model (GLM). All the generated models followed a binomial distribution and a "ClogLog Link" function (Zuur et al. 2007). The "ClogLog Link" function was chosen because our data have more zeros than ones (Zuur et al. 2007, 2009). The explanatory variables used were (a) bumblebee caste (BC) (factor variable of three levels: queen, worker, and male); (b) bumblebee species (BS) (factor variable of two levels: B. opifex and B. atratus); (c) total number of Kuzinia mites per bee (mite density=MD) (continuous variable); and (d) interaction between bumblebee species 
and total number of external mites per bee (according to the exploratory analyses only this interaction should be included in the final model):

$\operatorname{KAc}_{\mathrm{i}} \sim \operatorname{Binomial}\left(1, \pi_{\mathrm{i}}\right)$

$\mathrm{E}\left(\mathrm{KAc}_{\mathrm{i}}\right)=\pi_{\mathrm{i}}$ and $\operatorname{var}\left(\mathrm{KA}_{\mathrm{i}}\right)=\pi_{\mathrm{i}} \times\left(1-\pi_{\mathrm{i}}\right)$

$\operatorname{Clog} \operatorname{Logit}\left(\pi_{\mathrm{i}}\right)=\mathrm{BS}_{\mathrm{i}}+\mathrm{BC}_{\mathrm{i}}+\mathrm{MDi}+\mathrm{BS}_{\mathrm{i}} \times \mathrm{MD}_{\mathrm{i}}$

$\mathrm{KA}_{\mathrm{ci}}$ follows a binomial distribution with mean equal to 1 and a variance equal to $\pi_{\mathrm{i}}$. The " $\times$ " symbol denotes the interaction between the mite density and bumblebee species. The subindexes "i" for each variable represent data recorded for the " $\mathrm{i}$ " bumblebee. Calculations were done with the $\mathrm{R}$ software $(\mathrm{R}$ Development Core Team 2008). An additional statistical analysis (chi-square test) was performed to determine if Kuzinia mites have a preference for a particular body region of the bee.

\section{RESULTS}

\subsection{Distribution and localization of Kuzinia}

Upon inspection of bumblebee hosts, we noted a particular body zone where Kuzinia mites were clustered. Hypopi of the mites Kuzinia laevis, Kuzinia americana, Kuzinia affinis, and Kuzinia sp. were firmly attached. This special site was located in the propodeum, an area with shorter hair than other areas of the body. In many cases, it was observed that mites were grouped in a bare zone with a Y-shape (metapostnotal-propodeal limit). In its base, there is a small concave sector (Figure 1). This area was found in all three castes and was always related to phoretic deutonymphs displayed in an aggregated pattern. Areas of the host bodies occupied by mite clusters and the numbers, ranges, means, and SD of mites per cluster are presented in Table I.

\subsection{Host species and phoretic mites}

B. opifex A total of 122 bees were inspected and $44(36 \%)$ of them were harboring at least one mite. Kuzinia mites were observed infesting 30 of these bees (24.6\%). Kuzinia occurred on bees in all three castes particularly in the location previously described.
B. atratus A total of 546 specimens were studied and $53(9.7 \%)$ were infested with mites. Kuzinia mites infested 31 of the bees $(5.7 \%)$. As for B. opifex, Kuzinia was typically located in the propodeal area.

\subsection{Mite species infesting bumblebees}

The following mite species were recorded on $B$. atratus and $B$. opifex: $K$. laevis (Dujardin), K. americana (Delfinado and Baker), K. affinis (Delfinado and Baker), Kuzinia sp., Pneumolaelaps longanalis (Hunter and Husband), Pneumolaelaps longipilus (Hunter), Scutacarus acarorum (Goeze), and Tyrophagus putrescentiae (Schrank). Table II summarizes the diagnostic morphological characters of the mites identified. Mite prevalence, intensity, and abundance for each bumblebee species is described in Table III. B. atratus and $B$. opifex were infested by the same mite species, but $B$. atratus has generally higher indexes (prevalence, abundance, and intensity, $P<0.01)$. In addition, it was observed that queens and males were more infested (in terms of abundance, prevalence, and intensity) by mites than workers in both Bombus species $(P<0.01)$.

\subsection{Data modeling}

The initial data exploration demonstrated that there were no significant correlations among variables. GLM was, therefore, performed with all variables measured. In addition, outliers were not identified among data. Data exploration suggested including in the model only the interaction between mite load and bumblebee species. No other possible interactions between explanatory variables were suggested by the prior analysis.

GLM analysis indicated that Kuzinia mite aggregation on bumblebees was influenced by bee species and caste: mite aggregation was more evident in B. opifex than in B. atratus $(P<$ 0.01 ), although grouped mites were found in both species of bumblebees. Regarding the 

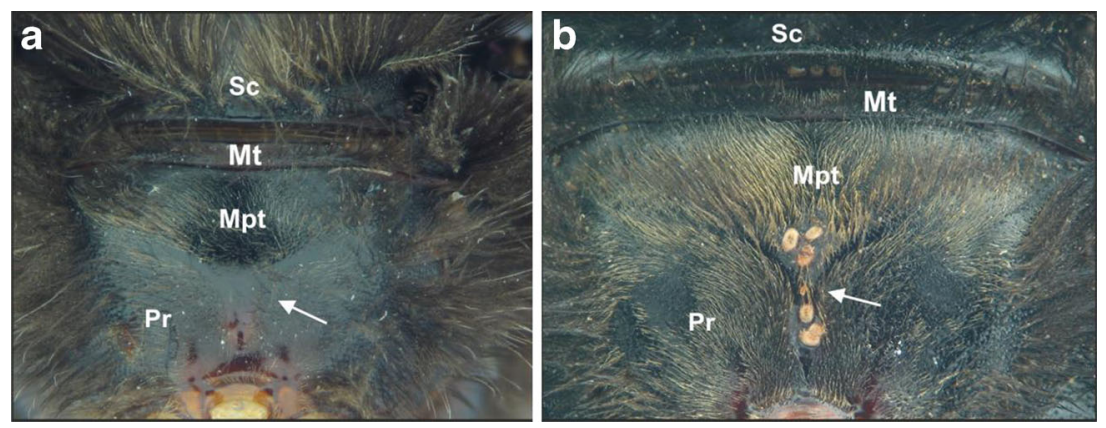

Figure 1. Posterior area of mesosoma of Bombus (F.) atratus. a Worker, the arrow shows the central area, the Y-shaped section (metapostnotal-propodeal limit). b Queen, showing aggregation of Kuzinia mites in the metapostnotal-propodeal limit. Sc scutellum, $P r$ propodeum, $M t$ metanotum, $M p t$ metaposnotum.

bumblebees' caste, mite aggregation was similar between males and queens $(P>0.05)$ but both had more aggregations than workers $(P<0.01)$. Finally, GLM analysis demonstrated that Kuzinia mite aggregation was not influenced by the number of mites $(P>0.05)$, even when the interaction with bumblebee species was considered $(P>0.05)$.

\section{DISCUSSION}

Several mite species are associated with bumblebees (Chmielewski and Baker 2008; Maggi et al. 2011a), most of which live inside the nest, feeding on nectar, pollen, debris, microorganism (fungi), and other mites (Chmielewski 1971, 1998; Chmielewski and Baker 2008). Generally, they are phoretic on bees, using them as transport to colonize new nests (Huck et al. 1998). Only K. laevis was reported as a parasite of Bombus spp. (Allen et al. 2007), but the nature of the interaction was disputed by Chmielewski and Baker (2008). Still, baseline information about the association between mites and bumblebees is scarce, and information about the cues that underlie mites' choice of host are not well understood.

Eight mite species belonging to different families were observed on bumblebees in this study. Genus Kuzinia (Acaroidea) was the most abundant with four species: $K$. laevis, $K$. americana, K. affinis, and Kuzinia sp. Kuzinia species have hypopial nymphs characterized by the reduction of the mouthparts, short legs, and a posterior sucker plate. This dispersive stage was reported to be phoretic on Bombus species. Hypopi were observed only in Kuzinia mites, whereas in the other genera, only free-living stages were observed. Genus Pneumolaelaps (Laelapidae) was the second highest in abundance, with two species recorded: P. longanalis and $P$. longipilus. These species can be visually

Table I. Number of Kuzinia mites found per bee in the body region, mites per cluster per area, and its SD and ranges.

\begin{tabular}{llllll}
\hline Bee's body region & $\begin{array}{l}\text { Number of } \\
\text { mites Kuzinia }\end{array}$ & $\begin{array}{l}\text { Number of } \\
\text { clusters }\end{array}$ & $\begin{array}{l}\text { Mites/ } \\
\text { cluster }\end{array}$ & SD & Range \\
\hline Groove between pronotum and scutum & $5^{*}$ & 1 & 5 & 0 & 0 \\
Under the tegula & $10^{*}$ & 2 & 5 & 2 & $3-7$ \\
Propodeum ("preferential area") & $583^{* *}$ & 30 & 19.6 & 25.3 & $2-44$ \\
Sterna & $12^{*}$ & 2 & 6 & 3 & $3-9$ \\
\hline
\end{tabular}

$* P<0.001$, statistically significant differences among body regions 


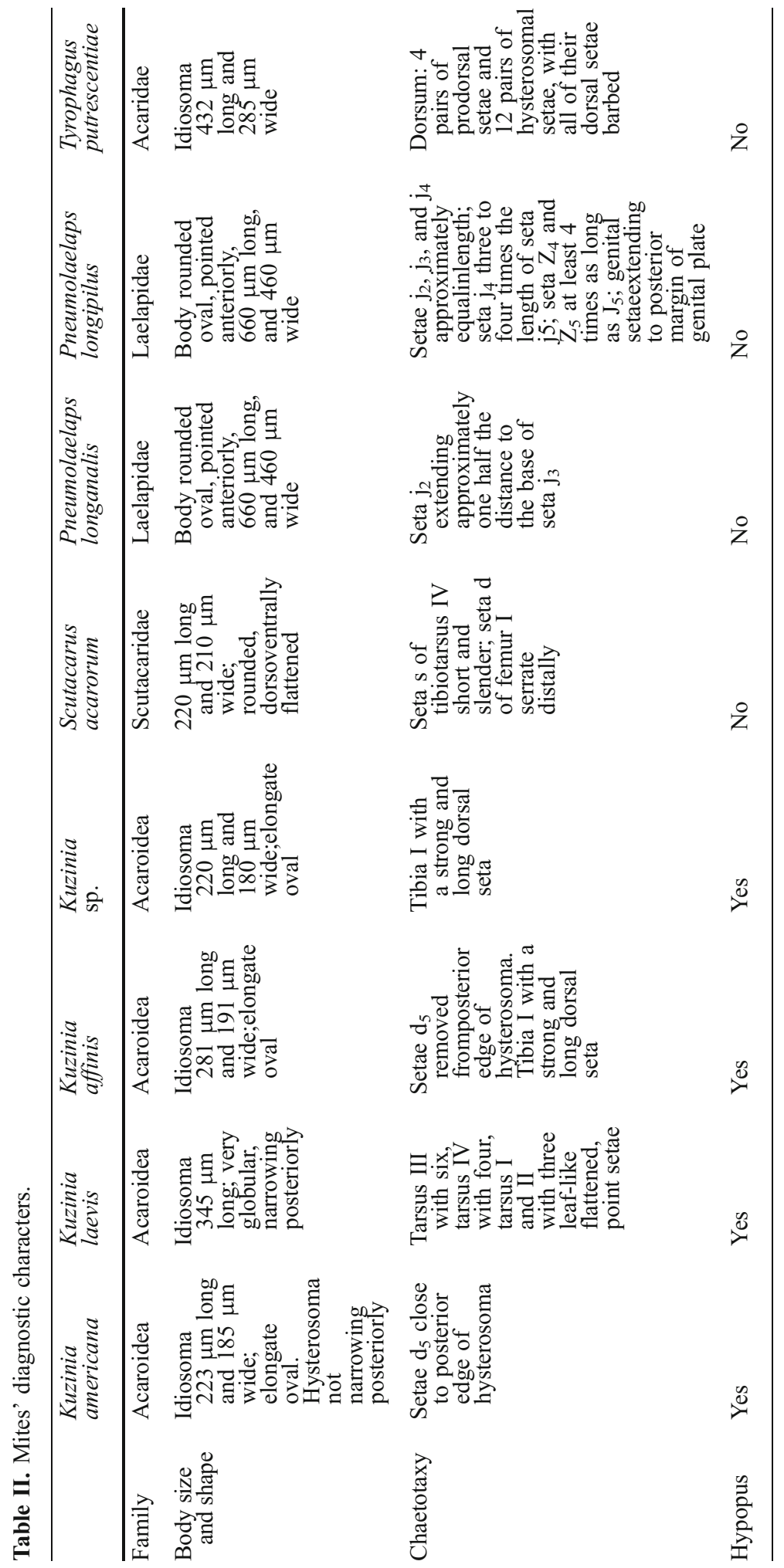


Table III. Mean prevalence (P), intensity (I), and abundance (A) of mites for each caste of Bombus spp.

\begin{tabular}{|c|c|c|c|c|c|c|c|}
\hline & \multirow[b]{2}{*}{ Index } & \multicolumn{3}{|c|}{ B. opifex } & \multicolumn{3}{|c|}{ B. atratus } \\
\hline & & Queen & Worker & Male & Queen & Worker & Male \\
\hline \multirow[t]{3}{*}{ Kuzinia laevis } & A & 0.6 & 0 & 0.66 & 1.88 & 0.04 & 0.08 \\
\hline & $\mathrm{P}$ & 20 & 0 & 12.5 & 17.65 & 1.85 & 4.08 \\
\hline & I & 3 & 0 & 5.25 & 10.67 & 2.25 & 2 \\
\hline \multirow[t]{3}{*}{ K. americana } & A & 0.7 & 0.15 & 0.62 & 0.7 & 0.04 & 0.08 \\
\hline & $\mathrm{P}$ & 20 & 6.25 & 12.5 & 5.88 & 0.93 & 4.08 \\
\hline & I & 3.5 & 2.4 & 5 & 12 & 4 & 2 \\
\hline \multirow[t]{3}{*}{ K. affinis } & A & 0.8 & 0.21 & 1.87 & 0.7 & 0.03 & 2.4 \\
\hline & $\mathrm{P}$ & 20 & 7.5 & 12.5 & 5.88 & 2.09 & 12.24 \\
\hline & I & 4 & 2.83 & 15 & 12 & 29.11 & 19.58 \\
\hline \multirow[t]{3}{*}{ Kuzinia sp. } & A & 1 & 0.34 & 0.66 & 0 & 0.002 & 0.28 \\
\hline & $\mathrm{P}$ & 30 & 7.5 & 12.5 & 0 & 0.2 & 3.06 \\
\hline & I & 3.33 & 4.5 & 5.25 & 0 & 1 & 9.33 \\
\hline \multirow[t]{3}{*}{ Tyrophagus putrescentiae } & A & 0 & 0 & 0.03 & 0 & 0.007 & 0 \\
\hline & $\mathrm{P}$ & 0 & 0 & 3.12 & 0 & 0.46 & 0 \\
\hline & I & 0 & 0 & 1 & 0 & 1.5 & 0 \\
\hline \multirow[t]{3}{*}{ Pneumolaelaps longanalis } & A & 5.1 & 0.47 & 0.09 & 1.94 & 0.04 & 0 \\
\hline & $\mathrm{P}$ & 70 & 13.75 & 9.37 & 23.53 & 2.78 & 0 \\
\hline & $\mathrm{I}$ & 7.28 & 3.45 & 1 & 8.25 & 1.33 & 0 \\
\hline \multirow[t]{3}{*}{ P. longipilus } & A & 0 & 0.05 & 0.12 & 0.29 & 0.002 & 0 \\
\hline & $\mathrm{P}$ & 0 & 2.5 & 6.2 & 17.65 & 0.2 & 0 \\
\hline & I & 0 & 0 & 0 & 1.66 & 1 & 0 \\
\hline \multirow[t]{3}{*}{ Scutacarus acarorum } & A & 0 & 0 & 0 & 0.06 & 0.01 & 1 \\
\hline & $\mathrm{P}$ & 0 & 0 & 0 & 5.88 & 0.23 & 1.02 \\
\hline & I & 0 & 0 & 0 & 1 & 5 & 4 \\
\hline
\end{tabular}

B. opifex $n=122$ (44 harboring mites) 10 queens, 32 males, and 80 workers. $B$. atratus $n=546$ (53 with mites), 17 queens, 98 males, and 431 workers

discriminated based on the size of their corporal setae: P. longipilus have longer setae compared to $P$. longanalis. These mites were found as unattached adults on the host. $P$. longanalis was the most abundant on $B$. opifex while $P$. longipilus was most abundant on $B$. atratus. $T$. putrescentiae (Acaridae) and $S$. acarorum (Scutacaridae) were the least abundant phoretic mites on both $B$. opifex and B. atratus. These results are similar to those reported by Maggi et al. (2011a), also in Argentina. Nevertheless, some mite species reported by Maggi et al. (2011a) were not found in the current study: Parasitellus fucorum was previously detected infesting $B$. atratus, but was not found in the present study. The same authors reported only two species of Kuzinia, while a total of four Kuzinia species were observed in the present study. This might be explained by the larger geography covered by this study or the season in which the studies were performed. It is known that environmental conditions and/or their variability could affect mite presence and abundance (Brandenburg and Kennedy 1982; Sabelis and Dicke 1985). Mite abundance, prevalence, and intensity were lower in $B$. opifex than those in $B$. atratus. This is potentially attributed to host distribution which, for $B$. 
opifex, is much more restricted (Abrahamovich et al. 2007). It should be more beneficial in terms of dispersal and niche colonization for mites to be phoretic on hosts with a wider distribution range; however, further research is needed to test this hypothesis.

Some species of xylocopine and halictid bees have true acarinaria on their body surfaces. It was postulated that this structure is apparently specialized to shelter mites and exhibits a high specificity between hosts and mites (Okabe and Makino 2002, 2008). The presence of an acarinarium might be considered as an important key driving the process of host selection. This hypothesis assumes that associated mites benefit hosts by destroying harmful pathogens or parasites (Eickwort 1994; O'Connor and Klompen 1999), although no supporting evidence exists. However, Klimov et al. (2007) suggested that acarinaria on apid bees were developed to control harmful mites. Whatever its biological significance, a direct consequence of having an acarinarium is grouping of mites. We suggest that the delimited section of the propodeal area where Kuzinia mites group and attach may be "preferred areas," although more information is needed to determine if the area is a functional acarinarium as described by Abrahamovich and Alzuet (1989) for solitary bees of genus Xylocopa. Additionally, future studies should evaluate other bumblebee species to determine if they have similar structures and, if so, if Kuzinia mites should be considered to be beneficial to their bumblebee hosts rather than parasites (Allen et al. 2007).

GLM analysis demonstrated that mite aggregation on Bombus spp. was influenced only by the caste and host species. Huck et al. (1998) suggested that behavioral preferences for particular castes of social bees are beneficial, particularly when the hosts' nests are annual. Mite aggregation was not influenced by the number of mites per host. Moreover, the number of mites per host is independent from the caste. These results suggest that there exist particular forces driving the mite aggregation. These "forces" or signals could be explained by chemical stimuli delivered only by the host (and not by mites, given that no relationship between the number of mites per host and castes were detected, as it was stated previously). Future studies should investigate if the Bombus castes produce different odors or kairomones that are attractive for mites and, if so, how they are detected by mites. Chemical signaling among mites and bees is well known. For example, in the parasite-host system Apis mellifera and Varroa destructor, 5-day-old bee larvae produce particular pheromones that are detected by female mites. As a consequence, Varroa mites infest the host, and the result is a grouping of mites around the bee larvae (Rosenkranz et al. 2010). Huck et al. (1998) reported that, in the field, deutonymphs of $P$. fucorum were phoretic on bumblebee workers and queens. In behavioral experiments, all castes proved to be attractive as carriers for mites; however, mites preferred queens that had hibernated as carriers over workers and queens. In addition, deutonymphs provided a choice switched from males to young queens but never transferred from a queen to a male. Their results suggest that deutonymphs preferentially attach to queens but may also use other castes for transport. Those dispersing on workers and males may try to switch to queens later. Host switching is possible during copulation and on flowers, where bees of all castes forage. For both $B$. atratus and $B$ opifex, mite aggregation was only detected in queens and males but not in workers. As workers do not make nests, their mites can only dislodge and wait for a queen visiting flowers or reinfest the nest. Mites on males can migrate to a queen or a queen's mites to males during copulation, possibly providing a greater opportunity to transfer and infest new nests. For that reason, it should be more successful for mites to infest queens and males than to infest workers. Worker bees only should be used as a valid option for transport, when mites are placed on flowers and workers arrive to them for collecting nectar or pollen and no other alternative is present (Schwarz and Huck 1997). However, future studies should test if worker-to-worker transference via flowers is a valid way to get to a new nest. 
More mites were found clustered in B. opifex than in B. atratus; however, we did not detect factors in these two species that could serve as an explanation for clustering. Future studies focused on the interaction between Bombus and mites will allow us to recognize the factors that influence phoresis and also to understand the strategies or mechanisms that allow mites to find and stay grouped over the body of the bees.

\section{ACKNOWLEDGMENTS}

The authors wish to acknowledge and thank to Pavel Klimov (University of Michigan, Department of Ecology and Evolutionary Biology), Diana Sammataro (ARS USDA), Victor H. Gonzalez (Southwestern Oklahoma State University and University of Kansas, Lawrence), and four anonymous reviewers for their critical reading and comments that improved an earlier version of the manuscript. We would like to acknowledge the curators of the following museums who provided access to host bee specimens used in this study: Colomo de Correa M.V (FIML), Sergio Roig Juñet (IADIZA), and Norma B. Diaz (MLP). We also wish to thank CONICET and UNDMP for their financial supports.

Agrégation spatiale des acariens phorétiques sur Bombus atratus et Bombus opifex (Hymenoptera: Apidae) en Argentine

\section{Bourdon / phorésie / Acari}

Räumliche Zusammenballung von phoretischen Milben auf Bombus atratus und Bombus opifex (Hymenoptera: Apidae) in Argentinien

\section{Hummeln / phoretische Milben / Zusammenballung}

\section{REFERENCES}

Abrahamovich, A.H., Bischoff de Alzuet, A.D. (1989) Relaciones foréticas entre ácaros (Acaridae y Chaetodactylidae) e Himenópteros (Anthophoridae, Xylocopinae). Rev. Soc. Ent. Arg. 47(1-4)

Abrahamovich, A.H., Tellería, M.C., Díaz, N.B. (2001) Bombus species and their associated flora in Argentina. Bee World 82, 76-87
Abrahamovich, A.H., Díaz, N.B., Lucia, M. (2007) Identificación de las "abejas sociales" del género Bombus (Hymenoptera, Apidae) presentes en la Argentina: clave pictórica, diagnosis, distribución geográfica y asociaciones florales. Revista Fac. Agron. Univ. Nac. La Plata. 106, 165-176

Allen, G.R., Seeman, O.D., Schmid-Hempel, P., Buttermore, R.E. (2007) Low parasite loads accompany the invading population of the bumblebee. Bombus terrestris in Tasmania. Insectes Soc. 54, 56-63

Brandenburg, R., Kennedy, G. (1982) Intercrop relationships and spider mite dispersal in a corn/ peanut agroecosystem. Entomol. Exp. et applic. 42, 269-276

Bush, A.O., Lafferty, K.D., Lotz, J.M., Shostak, A.W. (1997) Parasitology meets ecology on its own terms: Margolis et al. revisited. J. Parasitol 83(4), 575-583

Chmielewski, W. (1971) The mites (Acarina) found on bumble-bees (Bombus Latr.) and in their nests. Ekol. Pol. 19, 57-71

Chmielewski, W. (1977) Results of observations on associations of mites with insects (Acari - Insecta). Bull. Ent. Pol. 47, 59-78

Chmielewski, W. (1998) Mites (Acarina) occurring on social bees (Hymenoptera: Apidae: Apinae, Bombinae). Wiad. Entomol. 6, 201-206

Chmielewski, W., Baker, R. (2008) Mites (Acarina) phoretic on some common bumblebee species (Bombus spp.) from the Pulawy area (South-Eastern Poland). J. Apic. Sci. 52, 37-47

Donzé, G., Hermann, M., Bachofen, B., Guerin, M. (1996) Effect of mating frequency and brood cell infestation rate on the reproductive success of the honeybee parasite Varroa jacobsoni. Ecol. Entomol. 21, 17-26

Eickwort, G.C. (1994) Evolution and life-history patterns of mites associated with bees. In: Houck, M.A. (Ed.), Mites, Chapman and Hall, New York, pp. 218-251

Engel, M.S. (2000) Classification of the bee tribe Augochlorini (Hymenoptera: Halictidae). Bull. Am. Mus. Nat. Hist. 250, 1-89

Fain, A., Pauly, A. (2001) Notes on phoretic deutonymphs of mites (Acari) associated with Old World Megachilidae and Anthophoridae (Insecta, Hymenoptera), mainly from Madagascar 1. Families Chaetodactylidae, Acaridae, Histiostomatidae and Winterschmidtiidae (Astigmata). Belg. J. Entomol 3(1), 125-142

Fain, A., Engel, M.S., Flechtmann, C.H.W., O'connor, B.M. (1999) A new genus and species of Acaridae (Acari) phoretic on Thectochlora alaris (Hymenoptera: Halictidae: Augochlorini) from South America. Int. J. Acarol. 25(3), 163-172

Farish, D.J., Axtell, R.C. (1971) Phoresy redefined and examined in Macrocheles muscaedomesticae (Acarina: Macrochelidae), a predator of the house fly. Acarology 13, 16-29 
Floris, I. (1991) Dispersion indices and sampling plans for the honeybee (Apis mellifera ligustica Spin.) mite Varroa jacobsoni. Oud. Apicoltura 7, 161-170

Goulson, D. (2003) Bumblebees: their behavior and ecology. Oxford University Press, Oxford

Hadley, A. (2011) CombineZP - Free image stacking software for depth of field correction. Available from http://www.hadleyweb.pwp.blueyonder.co.uk/ CZM/combinezm.htm (accessed 21 September 2011)

Houck, M.A., O'Connor, B.M. (1991) Ecological and evolutionary significance of phoresy in the Astigmata. Annu. Rev. Entomol. 36, 611-636

Huck, K., Schwarz, H., Schmid-Hempel, P. (1998) Host choice in the phoretic mite Parasitellus fucorum (Mesostigmata: Parasitidae): which bumblebee caste is the best? Oecología 115, 385-390

Hughes, A.M. (1976) The mites of stored food and houses, 2nd edn. Technical Bulletin 9, Ministry of Agriculture, Fisheries and Food, London

Hunter, P.E. (1966) The genus Pneumolaelaps with description of three new species (Acarina: Laelaptidae). J. Kansas. Entomol. Soc. 39, 357-369

Hunter, P.E., Husband, R.W. (1973) Pneumolaelaps (Acarina: Laelapidae) mites from North America and Greenland. Fla. Entomol. 56, 77-91

Husband, R.W. (1968) Acarina associated with Michigan Bombinae. Pap. Mich. Acad. Sci. Arts. Lett. 53, 109-112

Klimov, P.B., Vinson, S.B., O’Connor, B.M. (2007) Acarinaria in associations of apid bees (Hymenoptera) and chaetodactylid mites (Acari). Invertebr. Syst. 21, 109-136

Klompen, H., Lekveishvili, M., Black, W.C. (2007) Phylogeny of parasitiform mites (Acari) based on rRNA. Mol. Phyl. Evol. 43, 936-951

Krantz, G.W., Walter, D.E. (2009) A manual of acarology, 3rd edn. Texas Tech University Press, Lubbock

Le Conte, Y., Arnold, G., Desenfant, P. (1990) Influence of the brood temperature and hygrometry variations on the development of the honey bee ectoparasite Varroa jacobsoni. Environ. Entomol. 19, 1780-1785

Maggi, M., Ruffinengo, S., Damiani, N., Sardella, N., Eguaras, M. (2009) A First detection of Varroa destructor resistance to coumaphos in Argentina. Exp. Appl. Acarol. 47(4), 317-320

Maggi, M., Damiani, N., Ruffinengo, S., Principal, J., De Jong, D., Eguaras, M. (2010) Brood cell size of Apis mellifera modifies the reproductive behavior of Varroa destructor. Exp. Appl. Acarol. 50(3), 269-79

Maggi, M., Lucia, M., Abrahamovich, A.H. (2011a) Study of the acarofauna of native bumblebee species (Bombus) from Argentina. Apidologie 42, 280-292

Maggi, M., Ruffinengo, S., Mendoza, Y., Ojeda, P., Ramallo, G., Floris, I., Eguaras, M. (2011b) Sus- ceptibility of Varroa destructor (Acari: Varroidae) to synthetic acaricides in Uruguay: Varroa mites' potential to develop acaricide resistance. Parasitol. Res. 108, 815-821

Maggi, M., Medici, S., Quintana, S., Ruffinengo, S., Marcángeli, J., Gimenez Martinez, P., Fuselli, S., Eguaras, M. (2012) Genetic structure of Varroa destructor populations infesting Apis mellifera colonies in Argentina. Exp. Appl. Acarol. 56(4), 309-318

McGinley, R.J. (1986) Studies of Halictinae (Apoidea: Halictidae). I: revision of New World Lasioglossum Curtis. Smithson. Contrib. Zool. 429, 1-294

Montgomery, D.C., Peck, E.A. (1992) Introduction to linear regression analysis. Wiley, USA

O’Connor, B.M. (1988) Coevolution in astigmatid mitebee associations. In: Needham, G.R., Page, R.P., Delfinado-Baker, R.M., Bowman, C. (eds.) Africanized honey bees and bee mites, pp. 339-346. EllisHorwood Ltd, Chichester

O’Connor, B.M., Klompen, J.S.H. (1999) Phylogenetic perspectives on mite-insect associations: the evolution of acarinaria. In: Needam, G.R., Mitchell, R., Horn, D.J., Welcourn, W.C. (eds.) Acarology IX, vol 2. Symposia, pp. 63-71. Ohio Biology Survey, Columbus

Okabe, K., Makino, S. (2002) Phoretic mite fauna on the large carpenter bee Xylocopa appendiculata circumvolans (Hymenoptera: Apidae) with descriptions of its acarinaria on both sexes. J. Acarol. Soc. Jpn. 11(2), 73-84

Okabe, K., Makino, S. (2008) Parasitic mites as parttime bodyguards of a host wasp. Proc. R. Soc. B 275, 2293-2297

Putatunda, B.N., Aggarwal, K., Kapil, R.P. (1983) Two new species of Kuzinia (Acarina: Acaridae) associated with bees (Hymenoptera) from India. Indian J. Acarol. 8(2), 57-62

Rosenkranz, P., Aumeier, P., Ziegelmann, B. (2010) Biology and control of Varroa destructor. J Invertebr. Pathol. 103(1), 96-119

Rózsa, L., Reiczigel, J., Majoros, G. (2000) Quantifying parasites in samples of hosts. J. Parasitol. 86, 228-232

Sabelis, M., Dicke, M. (1985) Long-range dispersal and searching behaviour. In: Helle, W., Sabelis, M.W. (eds.) Spider Mites, Their Biology, Natural Enemies and Control, vol. IB, pp. 141-160. Elsevier, Amsterdam

Sammataro, D., Gerson, U., Needham, G. (2000) Parasitic mites of honey bees: life history, implications, and impact. Annu. Rev. Entomol. 45, 519-548

Schwarz, H.H., Huck, K. (1997) Phoretic mites use flowers to transfer between foraging bumblebees. Insectes. Soc. 44, 303-310

Schwarz, H.H., Huck, K., Schmid-Hempel, P. (1996) Prevalence and host preferences of mesostigmatic mites (Acari: Anactinochaeta) phoretic on Swiss bumble bees (Hymenoptera: Apidae). J. Kansas. Entomol. Soc. 69(Suppl), 35-42 
Waiter, D.E., Beard, J.J., Walker, K.L., Sparks, K. (2002) Of mites and bees: A review of mite-bee associations in Australia and a revision of Raymentia Womersley (Acari: Mesostigmata: Laelapidae), with the description of two new species of mites from Lasioglossum (Parasphecodes) spp. (Hymenoptera: Halictidae). Aust. J. Entomol 41(2), 128-148

Zachvatkin, A.A. (1941) Tiroglifoidnye kleoeæi (Tyroglyphoidea). Fauna SSSR 6(1), 475
Zuur, A., Ieno, E., Smith, G. (2007) Analysing ecological data. Springer, New York

Zuur, A., Ieno, E., Walker, N., Saveliev, A., Smith, G. (2009) Mixed Effects Models and Extensions in Ecology with R. Springer, New York

Zuur, A., Ieno, E., Elphick, C. (2010) A protocol for data exploration to avoid common statistical problems. Methods Ecol. Evolut. 1, 3-14 